\title{
MAPPING AND ANALYSIS OF SURFACE GEOCOVER IN THE CHAPADÃO DO DIAMANTE - MG - BRAZIL
}

https://doi.org/10.4215/rm2019.e18010

\author{
Nazar, T I S M a* - Rodrigues, S C b
}

(a) Doctor by Universidade Federal de Uberlândia, Uberlândia - MG (Brasil)

ORCID: https://orcid.org/0000-0002-0257-1451. LATTES: http://lattes.cnpq.br/7464284211118706.

(b) Professor at Universidade Federal de Uberlândia, Uberlândia - MG (Brasil)

ORCID: https://orcid.org/0000-0002-5376-1773. LATTES: http://lattes.cnpq.br/0563872406702918.

Article history:

Received 12 February, 2019

Accepted 04 April, 2019

Published 15 May, 2019

\section{(*) CORRESPONDING AUTHOR}

Address: Instituto de Geografia - Universidade Federal de Uberlândia - Av. João Naves de Ávila 2121 - Progresso, Uberlândia - MG (Brasil) - Telefone: (34) 32394169 Ramal: 19

E-mail: silviogeografo@gmail.com

\section{Abstract}

The mapping of the surface geocovers and their association with lithological, structural and topographic aspects is the main objective of this research, carried out in Chapadão do Diamante (Chd), the extreme eastern portion of Serra da Canastra. With this purpose, aerogamaespectrometric data obtained from sub-orbital flights, high-resolution Google TM images and fieldwork with superficial material collection was used to create a Surface Geocover Map. The result show a correlation between these variables, either in their cartographic aspect, or through quantitative data. The structural aspects obtained through the delineation of linear features observable in shaded relief images, were analyzed from the overlapping to the Map of Surface Geocover and from a qualitative point of view indicated a distribution throughout the ChD area, demonstrating the main material differentiation in relation to the areas with the highest intensity of rocky outcrops and those with flat tops and hill slopes. In addition, the spatial and descriptive statistics analysis was preponderant for a better understanding of the distribution of the surface geocover data in relation to the aspects of the mapped relief units and the specific topographic aspects, such as slope and curvature of the relief.

Keywords: Surface materials. Quartzite reliefs. Geocartography. Air-gama spectrometry data

\section{Resumo / Resumen}

\section{MAPEAMENTO E ANÁLISE DE GEOCOBERTURAS NO CHAPADÃO DO DIAMANTE - MG - BRASIL}

O mapeamento e a compreensão das interações entre as geocoberturas do Chapadão do Diamante com os aspectos morfométricos e estruturais do relevo a partir da aplicação de rotinas de análise espacial e geoestatística são os principais objetivos desta pesquisa, realizada na porção extremo leste da Serra da Canastra (Minas Gerais, Brasil). O estudo das geocoberturas é importante para a pesquisa geomorfológica por permitir o entendimento da gênese, evolução e comportamento do relevo terrestre. Assim, ao considerar as especificidades geológico-geomorfológicas da área de estudo, constituída por um pacote de rochas quartzíticas com intercalações de filitos, que apresentam variações perceptíveis na distribuição das coberturas superficiais, entende-se que os elementos superficiais interferem e respondem de diferentes maneiras em relação à dinâmica e evolução da área.

Palavras-chave: Materiais superficiais. Relevos quartzíticos. Geocartografia. Dados aerogamaespectrométricos.

\section{MAPA Y ANÁLISIS DE GEOCOBERTURAS EN LA CHAPADÃO DEL DIAMANTE - MG - BRASIL}

El mapeo y la comprensión de las interacciones entre las geocoberturas del Chapadão del Diamante con los aspectos morfométricos y estructurales del relieve a partir de la aplicación de rutinas de análisis espacial y geoestadístico son los principales objetivos de esta investigación, realizada en la porción extremo este de la Serra da Canastra Minas Gerais, Brasil). El estudio de las geocoberturas es importante para la investigación geomorfológica por permitir el entendimiento de la génesis, evolución y comportamiento del relieve terrestre. Así, al considerar las especificidades geológico-geomorfológicas del área de estudio, constituida por un paquete de rocas quartzíticas con intercalaciones de filitos, que presentan variaciones perceptibles en la distribución de las cubiertas superficiales, se entiende que los elementos superficiales interfieren y responden de diferentes maneras en relación a la dinámica y evolución del área.

Palabras-clave: Palavras-clave: Materiales superficiales. Relevos en quartzito. Geocartografia. Datos aerogamaespectrométricos 


\section{INTRODUCTION}

Among the concepts that denominate the surface layer of Earth, there is the one of "soil", whose meaning is broad and used by great part of the sciences interested in the study of the surface, in special in pedological, edaphological, and engineering studies, and in part of geomorphological research, as illustrated by Tricart (1977); Brady (1983); Caputo (1988); Daniels and Hammer (1992); Dobos and Hengl (2009); Lepsch (2010); Guerra and Cunha (2013); Resende et al., (2014), among others. There is also the denomination of "surface materials" or "surface formations", whose registers are mostly found in geological and geomorphological studies, such as Trescases (1973); Carvalho and Rotta (1974); Campy and Macaire (1989); Lebret et al. (1993); Rodrigues (1998); Champagnac (2005); Soller et al. (2009); Simões et al. (2014); Simões et al. (2016); Guerra and Paisani (2013).

Currently, the literature often refers to the term "geocovers"; and the Espinhaço Ridge and the North of Minas Gerais hosted scientific research on the matter. The studies by Amorim, Augustin, and Messias (2014) and Neves et al. (2015) had their emphasis on Geomorphology and the evolution of the landscape, while Scott and Pain (2009) addressed the term "regolith".

According to Suguio (2010), the material components of the Earth's surface - despite the adopted denominations - result from pedogenetic processes, thus reflecting paleoclimatic conditions and behaviors of relatively-calm regional neotectonics. Morhange (2009) highlights that, from the geomorphologists' outlook, the surface formations in association with the erosion processes, cover the essential element of dynamic geomorphology.

According to Trescases (1973), the expression "surface formations" is applied to materials originating from bedrocks, susceptible to the action of geodynamic processes, nonetheless. In warm regions, the essential process is that of weathering, whose profile of change becomes a register of the climatic and morphological conditions that prevail in successive epochs since its elaboration. For Carvalho and Rotta (1974), rocks incessantly receive action from weathering processes - chemical and physical - which trigger off their alteration, transformation, and relocation, thereby originating the secondary formations that characterize surface formations.

Champagnac (2005) considers that surface formations are assimilated to soils in the pedological sense of the term, but their concept is still a relatively broad notion in the available literature, which opens several applications in virtue of research purposes. Furthermore, the author advances that they represent unconsolidated or movable continental formations, or secondarily consolidated. Additionally, when they result from chemical or biochemical alterations, the composition of the materials can be quite different from the original rock, and if it corresponds to the product of mechanical disintegration of the pre-existent rocks, the mineralogical and chemical composition will be similar to that of the parent rock.

The importance of the studies on surface formations, especially in geomorphological analysis, as stated by Bigarella, Mousinho, and Silva (1965), is reflected in these materials' capacity of presenting pieces of evidence in regards of the genesis, evolution, and behavior of Earth's relief. Such studies focus, on top of all, in the understanding of the Quaternary, period wherein cyclical climatic oscillations were controlling factors of the landscape evolution.

In face of the above, for this paper, the use of the term "geocovers" or "surface materials" is judged adequate, in function of the perspectives of geomorphological research in agreement with the proposed goals. That is because the use of "surface formations" may refer to a category of geological classification or lithostratigraphic, and thus lead to inadequate interpretations. Therefore, having the concepts of Campy and Macaire (1989) and Scott and Pain (2009) as a basis, we try to define a concept of geocovers that best adequate to the performed research.

On the one hand, Campy and Macaire (1989) considered surface formations as a movable or weakly consolidated surface or subsurface layer of variable width, composed by materials that have been physically or chemically altered in situ or resultant of transport and deposition, that lays on top of the bedrock. On the other hand, Scott and Pain (2009) refer to the term "regolith" as being the mantle that covers the whole relief of Earth. Regolith is also originated either in situ or per the transport of weathered material coming from rocks. Such definitions synthesize the meaning of geocovers, as resultants of the geomorphological dynamic.

Thus, geocovers, are understood as all materials that constitute the mantle of surface alteration 
that covers Earth's relief. They are rendered by physical or chemical processes, in situ or by transport and deposition, including the unconsolidated and movable materials, as well as the consolidated, such as rocky outcrops, which already are exposed to weathering processes. In this sense, the objectives of this paper include: to comprehend the interactions between the Diamante tableland with the morphometric and structural aspects of the relief, by applying routines of spatial analysis and descriptive geostatistics, and; to spatialize and to characterize the geocovers through remote sensing data.

The main proposal for the survey of the geocovers was to contribute to the geomorphological analysis, based on the understanding that all the surface elements interfere and respond in different ways to the relief's dynamic and evolution. The characterization of the geocovers was done to subsidize a better understanding of the genesis of the materials, as well as a study of the landscape-surface materials relations that focused on the role of the relief (topography) and of the litho-structural aspects in the spatial distribution of the different types of geocovers. It is understood that this approach is necessary in the Diamante Tableland, taking into consideration its geological-geomorphological specificities, which are greatly influenced by the existence of a cluster of quartzite rocks that have interleaving phyllites that imply in perceptible variations in the distribution of surface covers, at times with profiles and weathering mantle barely developed.

\section{STUDY AREA}

The Diamante Tableland $(\mathrm{ChD})$ is part of the Canastra Ridge and is located in the municipality of São Roque de Minas, some $320 \mathrm{~km}$ away from Belo Horizonte, the capital of the state of Minas Gerais, and approximately $300 \mathrm{~km}$ away from Uberlândia, in the Triângulo Mineiro region. Following the applied by Nazar and Rodrigues (2019), the delimitation of the area stars at the altimetric height of 1080 $\mathrm{m}$, altitude from which the escarpments that surround the $\mathrm{ChD}$ - which add up to an extension of 333 $\mathrm{km}^{2}$, begin (FIGURE 1). The highlighted elevation points are those that vary from an altitude of 1400 to $1500 \mathrm{~m}$.

From the geological-geomorphological outlook, the Canastra Ridge, as per Ab'Sáber's (2003) classification, is part of the transition area between the Domain of the Tropical-Atlantic Forested Hilly Areas and the Morphoclimatic Domain of the Interior Tropical Tablelands with Cerrado and Gallery Forests. In Ross's (2006) conception, the region pertains to the Plateaus and Ridges of Goiás-Minas relief compartment, in the context of the Brasília Stripe. Additionally, according to Saadi (1991), it is included in the Elevated Marginal Plateaus compartment, due to its adjacency to the São Francisco Craton.

In a more recent classification, Souza and Rodrigues (2014) represent the Canastra Ridge, and therefore the Diamante Tableland, as part of the morphostructural compartment of the Canastra Stripe, which is encompassed by the Upper Surface Morpho-sculptural Unit. This set, associated with the Babilônia Ridge, is under territorial demarcation in the Canastra Ridge National Park's (PARNA Canastra) full-protection conservation unit, established in 1972 (MMA/IBAMA, 2005).

Moreover, in a higher-detailed scale, Nazar and Rodrigues (2019) performed the partition of the ChD's relief, thereby acknowledging six classes of relief patterns. According to such authors, the distribution of the geomorphological units in the area results from the interaction of a complex system that factors in litho-structural aspects and climatic features. Additionally, they postulate the hypothesis on the characteristics of the surface material, as, for instance, the ferruginous concretionary layers, which can support and preserve the flat-topped summits because of their larger resistance to weathering processes. Thus, the authors present the classes of highly-dissected to gently-dissected relief, flattened relief, relief in quartzite ridges and structural escarpments. 


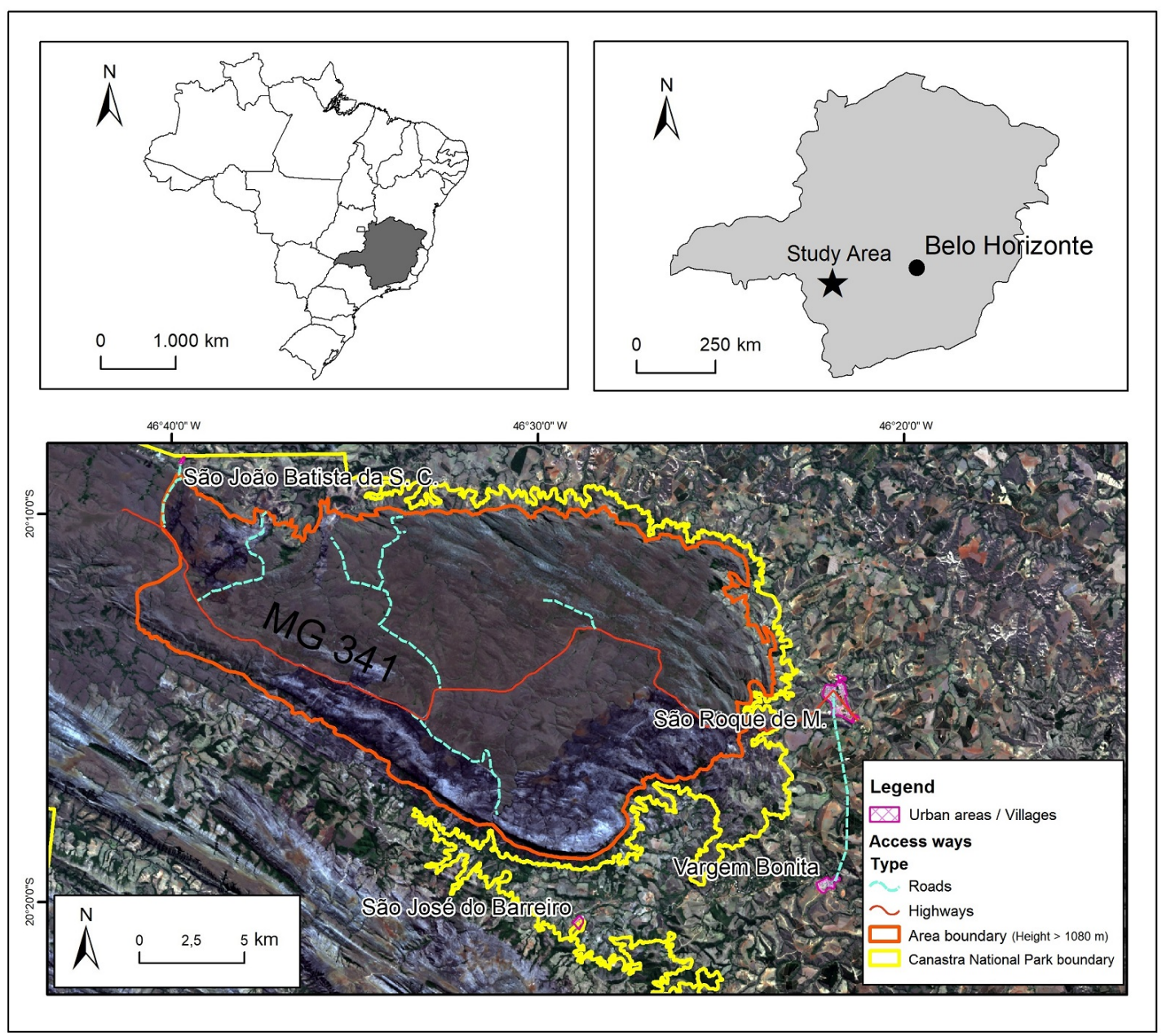

Figure 1 - The location of the study area

\section{OPERATIONAL PROCEDURES}

To spatialize the different units of geocovers - aiming to analyze the interrelation with relief patterns and litho-structural aspects - mapping techniques based on a cartographic analysis were applied in combination with field surveys, photointerpretation of images, aerogammaspectrometric data, collection in inspection points, and the use of pre-existent maps. Thus, the following materials were used:

a) Topographic Maps of the Brazilian Systematic Mapping, IBGE - Instituto Brasileiro de Geografia e Estatística (1970) - Scale 1:50.000.

b) Digital Model of the hydrological consistent terrain - Elaborated by the author according to the Topographic Maps IBGE (1970) - Scale 1:50.000.

c) Vector files and raster:

i. Vector file of the Topographic Map of Brazil to the Millionth - Page SF-23 (Serviço Geológico do Brasil -CPRM, 2003).

ii. Vector File of the Geology of Minas Gerais(Companhia de Desenvolvimento Econômico de Minas Gerais - CODEMIG, 2014).

iii. Vector File of the Geology of the Vargem Bonita Page (CODEMIG, 2015) -Scale 1:100.000.

iv. Vector file of the Relief Patterns (NAZAR; RODRIGUES, 2019) - Scale 1:50.000.

v. Google Maps/Earth Images.

vi. Images of the aerogammaspectometric survey of Minas Gerais (CODEMIG, 2005-2006) 
vii. UAV (Unmanned Aerial Vehicle) Images (Laboratório de Geomorfologia e Erosão dos Solos, UFU, 2017).

d) ArcGIS 10.2 e QGIS software.

Several authors indicate the use of semi-automated digital mappings for the study of soils or surface materials, such as Scull et al. (2003); Bishop; Minasny (2006); Hengl (2009); Hengl; Macmillan (2009), among others. For this paper, the manual mapping of the classes of geocovers in the Diamante Tableland was chosen for two main reasons: the lack of freely-available high-definition satellite images with electromagnetic spectral ranges, which would allow supervised and non-supervised classifications; and the exclusive option of image visualization through the free platforms of Google Maps/Earth, which also rendered impossible a semi-automated or fully-automated classification.

Therefore, the visual interpretation of classes was the chosen technique for the mapping of the geocovers. It was based on the high-definition images of Google Maps/Earth, with manual digitalization through the QGIS software. This is underpinned by the methods of visual interpretation and manual digitalization used by Vink (1968); Hengl and Rossiter (2003); Diniz, Oliveira, and Augustin (2004; 2005); Simões et al. (2016); and Jacobson et al. (2015). In addition to that, the images from aerogammaspectometric data, whose tests, theoretical underpinnings and field comparisons showed its great capacity in the qualitative identification of surface materials, especially those related to the detrital-ferruginous geocovers. As a complement to the interpretation, the available topographic data were also used, as Figure 2 shows.

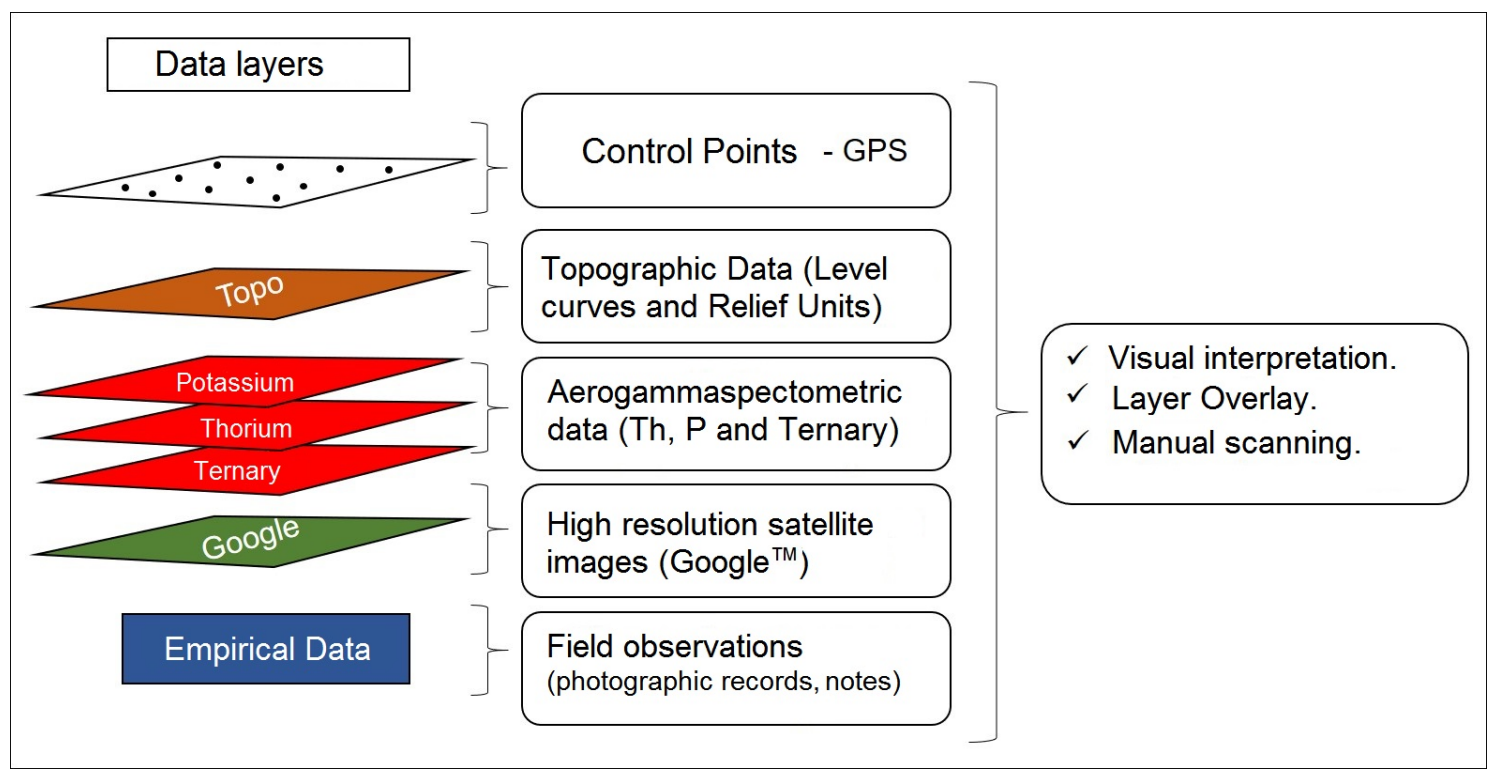

Figure 2 - Data layers used for the spatialization and manual digitalization of the geocovers.

We consider that this is an alternative solution for the spatialization of the geocovers, whose result must go through field verification (post-mapping field work) and also through the spatial analysis to subsidize the correlation with other land surface parameters (LSPs), such as altitude, declivity, and curvature; besides the correlation with the existent relief patterns.

Thus, the parameters used for the classification and appreciation of the classes of geocovers were applied bearing in mind not only those rendered by pedogenetic activity, but also any type of material on the surface, that have been altered in situ by physical or chemical processes, or that result from transport and deposition. The nomenclature applied to the classes of geocovers tried to include observable aspects of granulometry (assessed in fieldwork). Furthermore, the predominant genesis could be inferred after overlapping the classified units to information on the curvature.

An interpretation key based on aspects of roughness, shading, color, and texture, was developed for the Google Maps/Earth Images. Such parameters allow differentiation of the patterns of patterns and shape of similar geocovers. Further, the combination of these patterns reflects the unicity of each relief 
form or geocover. The field observations were based on the collection in inspection points with GPS, pictures and description of the topographic position, observable characteristics of the material, and landscape conjuncture.

The parameters for the qualitative analysis of the aerogammaspectometric data, on their turn, included the assessment of data regarding the radioelements Thorium (Th) and Potassium (K), as well as the Ternary map, as described below. The rates of Uranium (U) were not individually assessed as those of $\mathrm{K}$ and Th, for it was considered little representative; Herrmann et al. (2010) had already indicated its behavior as being little understood in the literature.

In this sense, the used qualitative parameters were:

- The concentration of $\mathrm{K}$ declines as weathering increases. That is due to $\mathrm{K}$ being highly soluble in most weathering environments, and therefore being quickly leached out of the profile (WILFORD, 2014; WILFORD; MINTY, 2007).

- High quantities of Th indicate the presence of lateritic concretions (SIMÕES et al., 2015). According to Herrera (2016), lateritic areas tend to have low concentrations of $\mathrm{K}$ and high concentrations of Th and $\mathrm{U}$; the rates of the latter usually being lower than those of Th.

- U and Th are associated with resistant minerals and, when released due to weathering, are easily absorbed in clayey minerals, oxides (Fe and Al) and organic matter (WILFORD, 2014; WILFORD; MINTY, 2007).

- Low quantities of the radioactive elements indicate the predominance of quartzites, once these characteristically have low levels of such elements in their compositions (SIMÕES et al., 2015).

- Low levels of $\mathrm{K}$ also indicate the presence of the mineral quartz (SIMÕES et al., 2015).

- Colluvial covers present low to medium rates regarding the percentual of K (SIMÕES et al., 2015).

Secondarily, after the performed steps, an analysis of the geocovers in function of their relations with the litho-structure, relief units, and land surface parameters (LSPs) was run. The structural aspects, here understood as resulting from Quaternary neotectonics as indicated by Saadi (1991), brought out lineaments in the landscape of the Diamante Tableland that give pieces of evidence towards structural control. These were analyzed from the development of a lineaments map that overlapped the classes of geocovers that had been previously identified. Furthermore, in order to do that, the fact that the area lays on top of a relatively uniform parent material - formed by pure quartzites to micaceous and interleaving phyllites - was considered.

The lineaments map was based on the methods proposed by Corrêa and Fonsêca (2010), Oliveira et al. (2009), and Hiruma and Roccomini (1999). The procedures considered:

- Lineaments as linear typologies of the topography, observable in aerial or satellite images, being able to present structural alterations or ruptures (CORREA; FONSÊCA, 2010). Its analysis must be done based on the extraction of information from a DEM / DTM, which consequently brought the necessity to make several different products with the use of the ArcMAP (ArcGIS) software.

- Relief shading images rendered with azimuth illuminations in eight directions (N, S, E, W, NE, $\mathrm{SE}, \mathrm{NW}, \mathrm{SW}$ ), from which the images that provided the best results were selected. For the $\mathrm{ChD}$, the best azimuths - those that highlighted the lineaments - were N, NW, NE, and SW. The standard value for the Sun's altitude in relation to the horizon was measured in degrees and it was equivalent to $45^{\circ}$.

- Extraction of lineaments in accordance with the aligned ridges, valley floors, and tonalities - as per the visual interpretation of the shading maps - with manual vectorization. For the analysis of the lineaments, only those above $1000 \mathrm{~m}$ were included, due to the map scale. The vector drainage network was overlapped to the images in order to aid in the lineament.

- Extraction of azimuths from the lineaments indicate the preferable directions, classification, and statistical analysis. Rosette diagrams that indicate the preferable directions of the lineaments were developed using the Rockworks 17 software.

The spatial analysis, with the application of geostatistics, allowed the association and complementation of the manual method with automatically-extracted topographical parameters (LSPs), thereby indicating the relief-geocovers interrelation. The dependence between these factors is 
demonstrated by Scull et al. (2003); McBratney; Mendonça Santos, and Misnasny (2003); Bishop and Minasny (2006); Dobos and Hengl (2009), Hengl and Macmillan (2009), Florsinky (2012).

In this sense, the spatial analysis, according to Câmara et al. (2004), emphasizes the measurement of properties and relations about the spatial localization of the phenomenon under study, which can be called geographical phenomenon. Accordingly, the comprehension of the spatial relation between data is capable of providing a better understanding of the processes and phenomena that occur on Earth's surface. Therefore, the stage of spatial analysis and application of geostatistics consisted in the analysis of data on geocovers in relation to the units of relief pattern and topographical aspects, and based on the DTM and its by-products, such as declivity and curvature. These relations were selected bearing in mind the application of tests through the tools "Zonal Statistics as Table" and "Total Histogram", available in the Spatial Analysis set of ArcMAP. They were used with the goal of calculating the average and standard deviation (standard error) for each class of geocovers, seeking, as a result, to identify the spatial relations between the geocovers and the relief units.

\section{RESULTS}

The mineralogical aspects indicated by the aerogammaspectometric images gave special evidence to the differentiation of the areas with the presence of ferruginous geocovers - and, at times, concretionary materials - usually associated with the flat tops, as well as the areas with quartzitic rocky outcrops. Such observations were made possible on the basis of the presented by Wilford (2014) and Wilfor and Minty (2007), who championed that the radioelements present in the surface materials and rocks, represented by $\mathrm{K}$, Th, and $\mathrm{U}$, respond in different ways to the weathering and pedogenesis rates.

The analyzed images include the distribution of $\mathrm{K}$ and Th, especially the latter, due to its tendency to accumulate in heavily-weathered areas, occurring in association with the Fe oxides and clays; whereas $\mathrm{K}$ tends to be removed, therefore being characterized with low concentrations in areas of high weathering. Moreover, the fact that $\mathrm{K}$ and $\mathrm{Th}$ are absent of the quartzitic materials contributed to the distinction of the materials overlapping such areas in the Diamante Tableland.

In this sense, as Figure 3-A presents, the shades of blue and violet indicate higher concentrations of Th, whereas shades oscillating between yellow and red point to areas with lower concentrations of this element. By overlapping such data layer to the topographic information or to the relief units map, the relation between flat tops and smooth hills and higher concentrations of Th, which happens in the central area of the $\mathrm{ChD}$, is notorious. The relief pattern in quartzitic ridges - corresponding to the pure quartzite existent in the area that resists weathering processes due to its higher resistance - accordingly, is highlighted in the reddish shades that indicate the decline of the radioelement. In some areas in the NW portion of the map, in between the well-defined quartzitic ridges, flattened portions occur, as pointed in the relief map. These present higher concentrations of $\mathrm{Th}$, therefore indicating the presence of a material with a higher degree of weathering.

Figure 3-B presents, in the same fashion, the distribution of $\mathrm{K}$ in the area. The figure indicates that the relief classes associated with quartzitic rocky outcrops have the smallest concentrations of this radioelement. On the other hand, the larger proportions of $\mathrm{K}$, although smaller than those of $\mathrm{Th}$, occur in the central part of the Diamante Tableland, in lower topographic positions than the tops occupied by Th, nevertheless. Thus, $\mathrm{K}$ mainly appears in areas of midslopes and valley floors, thus indicating its movement with the fluxes from the top to the talweg, due to its higher facility in being leached. 


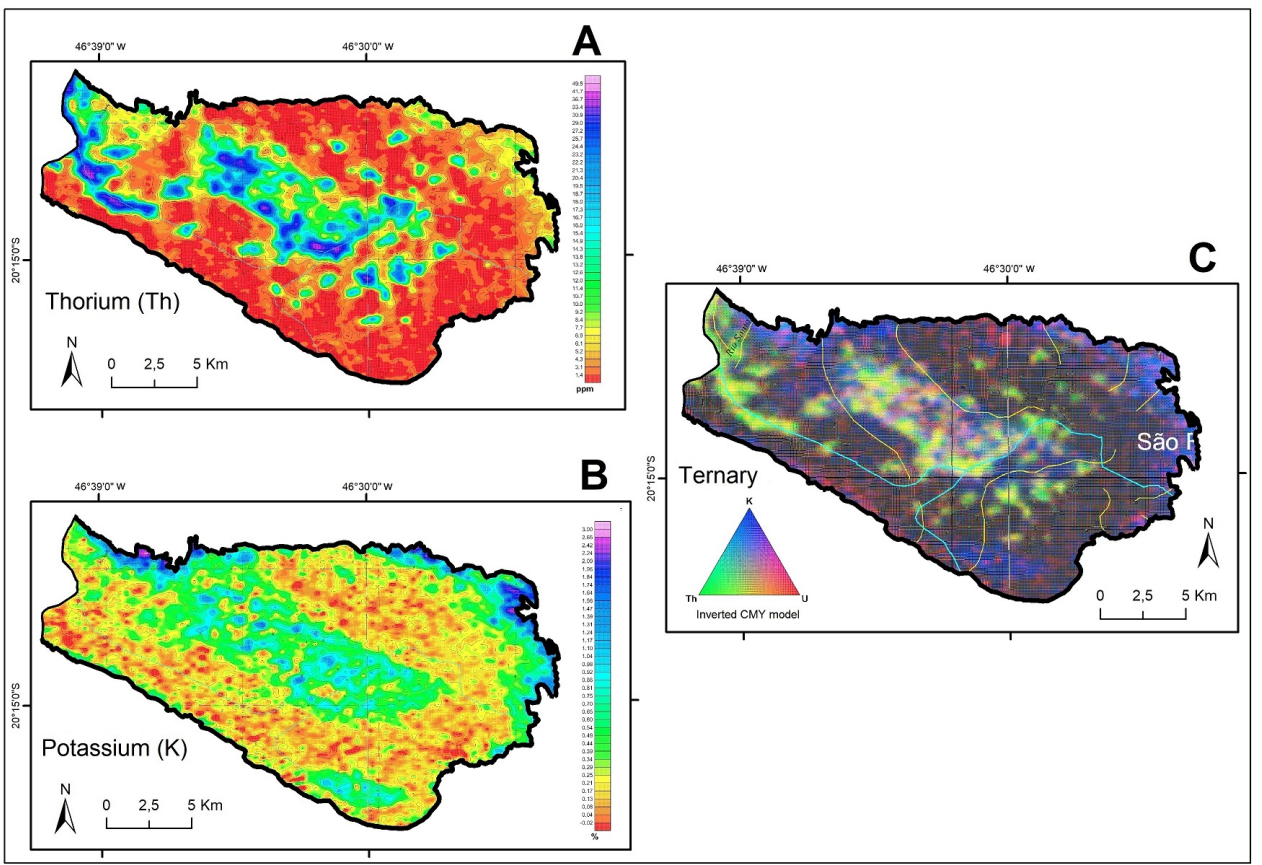

Figure 3 - Concentration maps for the radioelements in the Diamante Tableland. A) Thorium; B) Potassium; C) Ternary.

Figure 4 - which corresponds to a sample area that permeates areas of flat tops, valley floors, and quartzitic ridges - presents the observed pieces of evidence collected from the analysis of the three aerogammaspectometric maps.

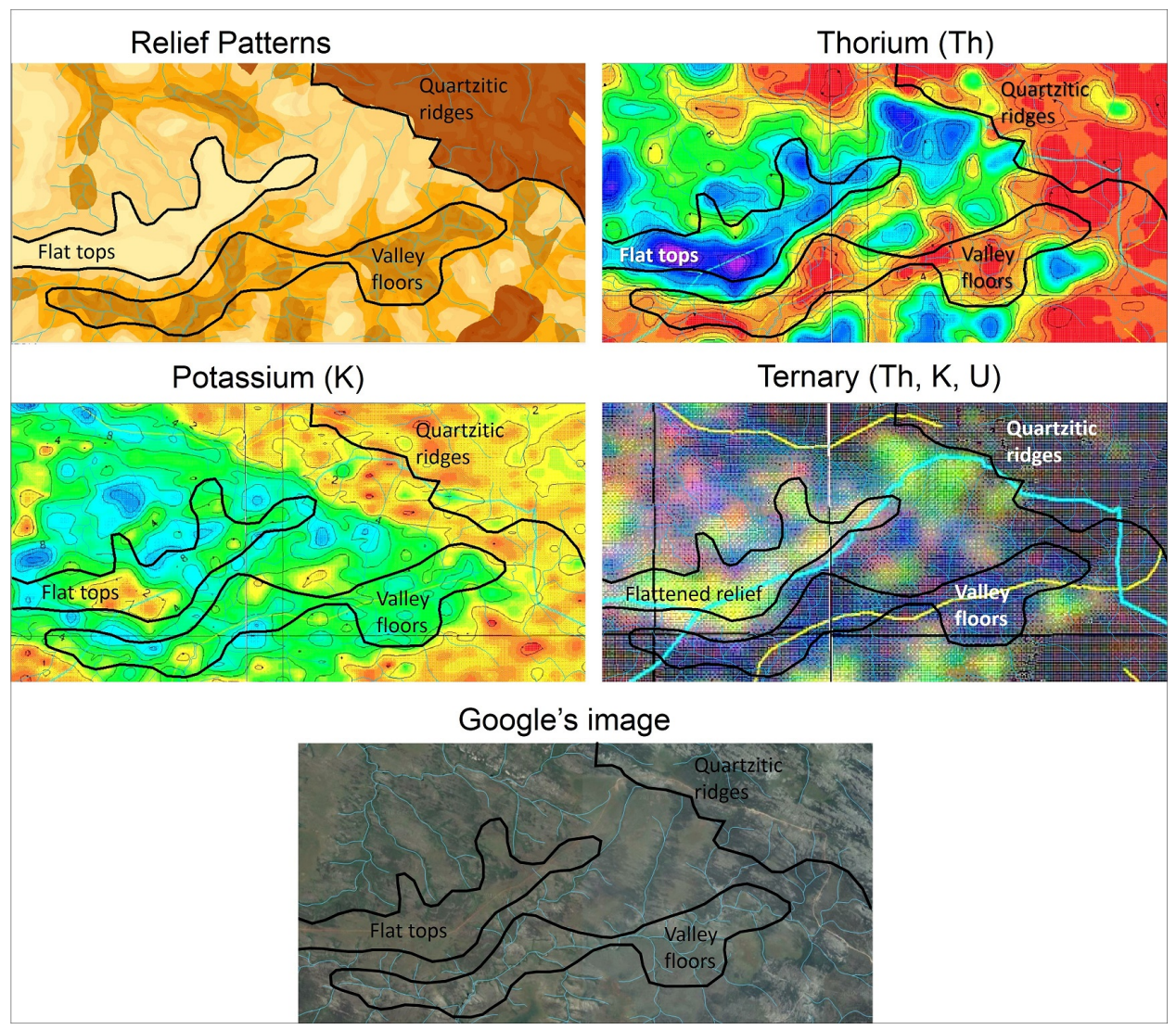

Figure 4 - Representation of the overlapping of the Relief Pattern Maps, Th, K, and Ternary. 
On a structural perspective, the analysis of the lineaments identified through the DTM-HC relief shading models together with the geocovers map, allowed the observation of three great structural axes in the Diamant Tableland. The first axis (N-NE sector) is related to the occurrence of elongated quartzitic ridges, which are overlapped by gravel-sandy materials and abundant rocky outcrops (at times with block chaos) as well as with clear structural control of the drainage network, whose watercourses fit in rectilinear valleys cutting in an NW-SE direction. The second axis, which contemplates the central part of the $\mathrm{ChD}$ also occurs in the NW-SE direction. It is characterized by the distribution of the materials of flat tops to gently-dissected relief, such as the sandy-clayey-ferruginous and gravel-sandy geocovers, and by the marked presence of $\mathrm{Fe}$ and $\mathrm{Al}$ oxides and hydroxides. Finally, the third axis corresponds to the S-SW sector. It is marked by elongated quartzitic ridges and the presence of gravel-sandy materials with or without block chaos.

Such evidence can provide indications of change in the lithological type existent in the central area of the $\mathrm{ChD}$, whose characteristics led to the greater incidence of the weathering processes for the pedogenetic evolution of the recumbent materials on the surface. This situation can also be attributed to the proportions of the radioelements present there, once the rates of Th and $\mathrm{K}$ are high in the central axis in comparison with the other two structural axes. Usually, according to Ribeiro, Mantovani, and Louro (2013), the $\mathrm{K}$ is associated with micaceous, feldspathic, and quartz-feldspathic metamorphic rocks, such as phyllites, schists, and gneisses, among other igneous and sedimentary rocks. The phyllites and the micaceous quartzites are the representants in the study area. The Th, on its turn, remains in the environment because of its smaller geochemical mobility and when in its free state - which is rendered by the mineral breakdown caused by weathering - it is easily retained in the Fe oxides and hydroxides and in the clayey colloids.

Figure 5 illustrates the relation between the lineaments and the direction of the features in the NW-SE direction, as the Rosetta diagram presents. The above-mentioned structural axes, which were identified through the merge of several lineaments in the same directional sequence with the framework of the drainage network under this very same linearity, are also represented. The small altimetric difference from one axis to another is notorious, as observed in the SW-NE topographical profile in the figure. That means the linearities seem to represent fractures, or deformations by ruptures, which may be separating the block or the rock layers along which no movements occurred.

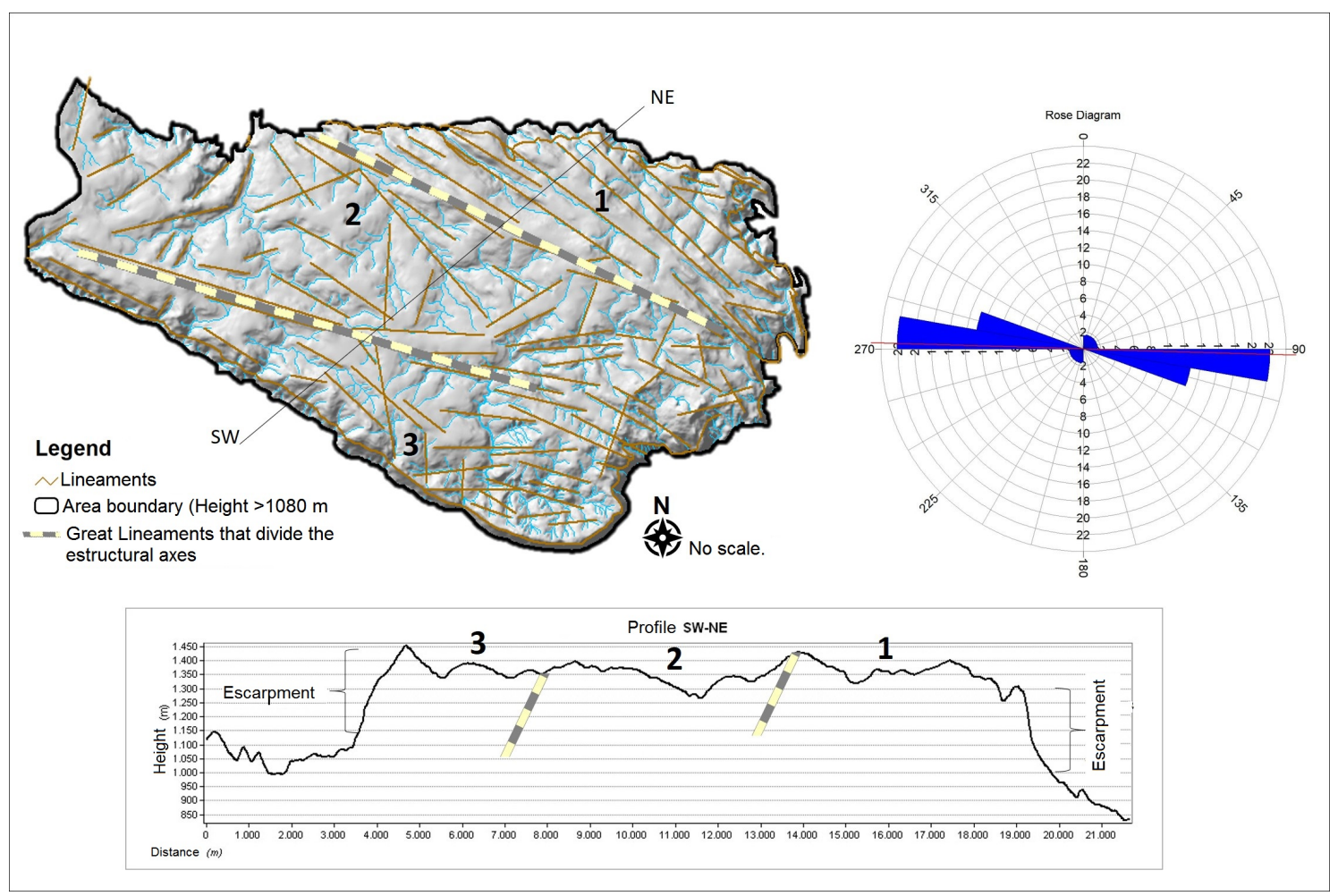

Figure 5 - Characterization of the Diamante Tableland Lineaments. 
The geocovers map was made based on the identification of 11 (eleven) classes of surface materials by the application of the described methods and techniques. The variability of these materials was characterized - depending on the possibilities - by the relative definitions of the granulometric type, weathering process, and predominant mineralogy. There were classes that were classified as undifferentiated because of the lack of parameters to define their predominant aspects. However, the spatialization of the geocovers reflects the reaction of the substrate to the relief patterns and the climate types wherein the region is.

Chart 1 synthesizes the classes of geocovers and their correspondent areas within the limit of altitudes above $1080 \mathrm{~m}$. It is observed that sandy, gravely, and rocky outcrops, compose more than half of the ChD's geocovers, which indicates the prominent role of the lithological type present there: the quartzite. Moreover, around $20 \%$ of the area was recognized with the presence of ferruginous materials, even with significative occurrences of lateritic concretions.

\begin{tabular}{|c|c|c|c|}
\hline Classes & $\begin{array}{l}\text { Area } \\
(\%)\end{array}$ & $\begin{array}{l}\text { Associated relief patterns, according to } \\
\text { Nazar and Rodrigues (2019) }\end{array}$ & $\begin{array}{l}\text { Associated } \\
\text { gammaspatometric aspects }\end{array}$ \\
\hline $\begin{array}{l}\text { Gravel-sandy materials } \\
\text { with block chaos }\end{array}$ & 23,07 & $\begin{array}{l}\text { Predominate in the areas with dissected relief in } \\
\text { wavy hills and also in the set of quartzitic } \\
\text { ridges. }\end{array}$ & $\begin{array}{l}\text { Low or no concentration of any } \\
\text { of the three radioelements Th, } \\
\mathrm{K} \text {, and } \mathrm{U} \text {. }\end{array}$ \\
\hline $\begin{array}{l}\text { Undifferentiated gravel- } \\
\text { sandy materials }\end{array}$ & 20,09 & $\begin{array}{l}\text { Occupy great part of the area, covering } \\
\text { dissected relief that compose wavy to highly- } \\
\text { waved hills. }\end{array}$ & $\begin{array}{l}\text { Low concentrations of Th and } \\
\text { low to average concentrations of } \\
\text { K. }\end{array}$ \\
\hline Rocky outcrops & 16,24 & $\begin{array}{l}\text { Especially occur in the pattern of elongated } \\
\text { quartzitic ridges. }\end{array}$ & $\begin{array}{l}\text { Low or no concentration of any } \\
\text { of the three radioelements Th, } \\
\mathrm{K} \text {, and } \mathrm{U} \text {. }\end{array}$ \\
\hline $\begin{array}{l}\text { Organic matter (peat } \\
\text { bogs) associated with } \\
\text { valley floors and humid } \\
\text { areas }\end{array}$ & 8,97 & $\begin{array}{l}\text { Predominate in the highly-dissected reliefs, } \\
\text { associated with valley floors. }\end{array}$ & $\begin{array}{l}\text { Average to low concentration of } \\
\text { Th, and high, average, and low } \\
\text { concentrations of K, all over the } \\
\text { Tableland. }\end{array}$ \\
\hline $\begin{array}{l}\text { Ferruginous bioturbation } \\
\text { materials ("murundum" } \\
\text { fields) or with } \\
\text { ferruginous concretions }\end{array}$ & 8,87 & $\begin{array}{l}\text { Mainly cover the gently-dissected relief areas, } \\
\text { adjacent to the central sector's flat tops. May } \\
\text { also occur in the flat tops themselves and in the } \\
\text { valley floors, anticipating the peat bogs. }\end{array}$ & $\begin{array}{l}\text { Average concentrations of Th } \\
\text { and high concentrations of } \mathrm{K} \text {. }\end{array}$ \\
\hline $\begin{array}{l}\text { Undifferentiated colluvial } \\
\text { materials }\end{array}$ & 5,90 & Occur in the escarpments' foothills. & $\begin{array}{l}\text { Low concentrations of Th and } \\
\text { average to low concentrations of } \\
\text { K. }\end{array}$ \\
\hline $\begin{array}{l}\text { Sandy-clayey-ferruginous } \\
\text { materials or with } \\
\text { ferruginous concretions }\end{array}$ & 5,52 & $\begin{array}{l}\text { Occupy the flat tops, especially those in the } \\
\text { central and western area. }\end{array}$ & $\begin{array}{l}\text { Very high to high concentrations } \\
\text { of Th, and low concentrations of } \\
\mathrm{K} \text {. }\end{array}$ \\
\hline $\begin{array}{l}\text { Gravel-sandy materials } \\
\text { with ferruginous } \\
\text { concretions }\end{array}$ & 3,75 & $\begin{array}{l}\text { Are present in the eastern flat tops, adjacent to } \\
\text { the elongated ridges of this sector. }\end{array}$ & $\begin{array}{l}\text { Average to high concentration } \\
\text { of } \mathrm{Th} \text { and average concentration } \\
\text { of } \mathrm{K} \text {. }\end{array}$ \\
\hline $\begin{array}{l}\text { Gravel-sandy materials } \\
\text { with organic layer }\end{array}$ & 3,40 & $\begin{array}{l}\text { Occur in flat tops and dissected relief in the } \\
\text { form of smooth hills, in the south-southeastern } \\
\text { portion of the area. }\end{array}$ & $\begin{array}{l}\text { Low concentrations of Th and } \\
\mathrm{K} \text {. }\end{array}$ \\
\hline $\begin{array}{l}\text { Undifferentiated Sandy- } \\
\text { clayey materials }\end{array}$ & 3,28 & $\begin{array}{l}\text { Prevail in the areas of dissected relief in smooth } \\
\text { to wavy hills, especially in the midslopes of the } \\
\text { central and western sectors. }\end{array}$ & $\begin{array}{l}\text { High to average concentration of } \\
\mathrm{K} \text { and average concentrations of } \\
\text { Th. }\end{array}$ \\
\hline $\begin{array}{l}\text { Undifferentiated } \\
\text { bioturbation materials }\end{array}$ & 0,91 & $\begin{array}{l}\text { Occur in non-associated areas to the } \\
\text { adjacencies of ferruginous flat tops that occupy } \\
\text { areas that antecede the lower parts of the } \\
\text { slopes. }\end{array}$ & $\begin{array}{l}\text { Average to low concentrations } \\
\text { of Th and average } \\
\text { concentrations of } K \text {. }\end{array}$ \\
\hline
\end{tabular}

Chart 1 - Classes of surface materials or geocovers and predominant aspects in the study area

Furthermore, Figure 6 presents the Tableland's Geocovers Map, from which it is possible to observe the different classes and trends. Additionally, the descriptive geostatistical analyses - which will support the better understanding of the spatial relations between the geocover units and the area's topographical aspects - will be forwarded further on. 


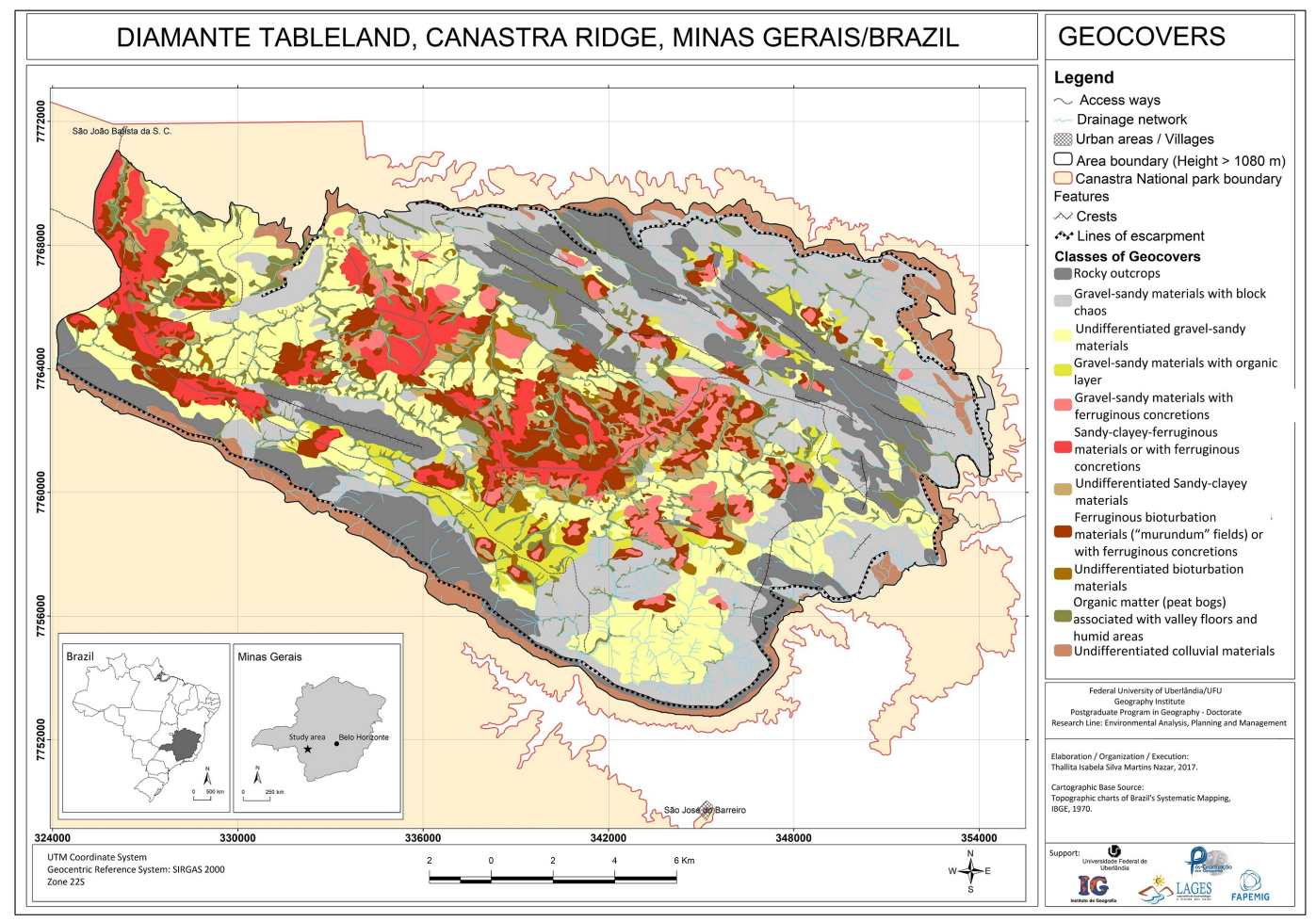

Figure 6-Geocovers Map of the Diamante Tableland.

Moving on to the zonal statistical analysis, the data on the physical environment of the Diamante Tableland present trends that indicate an important interrelation between them. Moreover, in regard to the distribution of the geocovers on the relief units, the prevailing patterns in the area could be illustrated. The basis for such analysis is in the geomorphological mapping performed by Nazar and Rodrigues (2019), which Figure 7 displays.

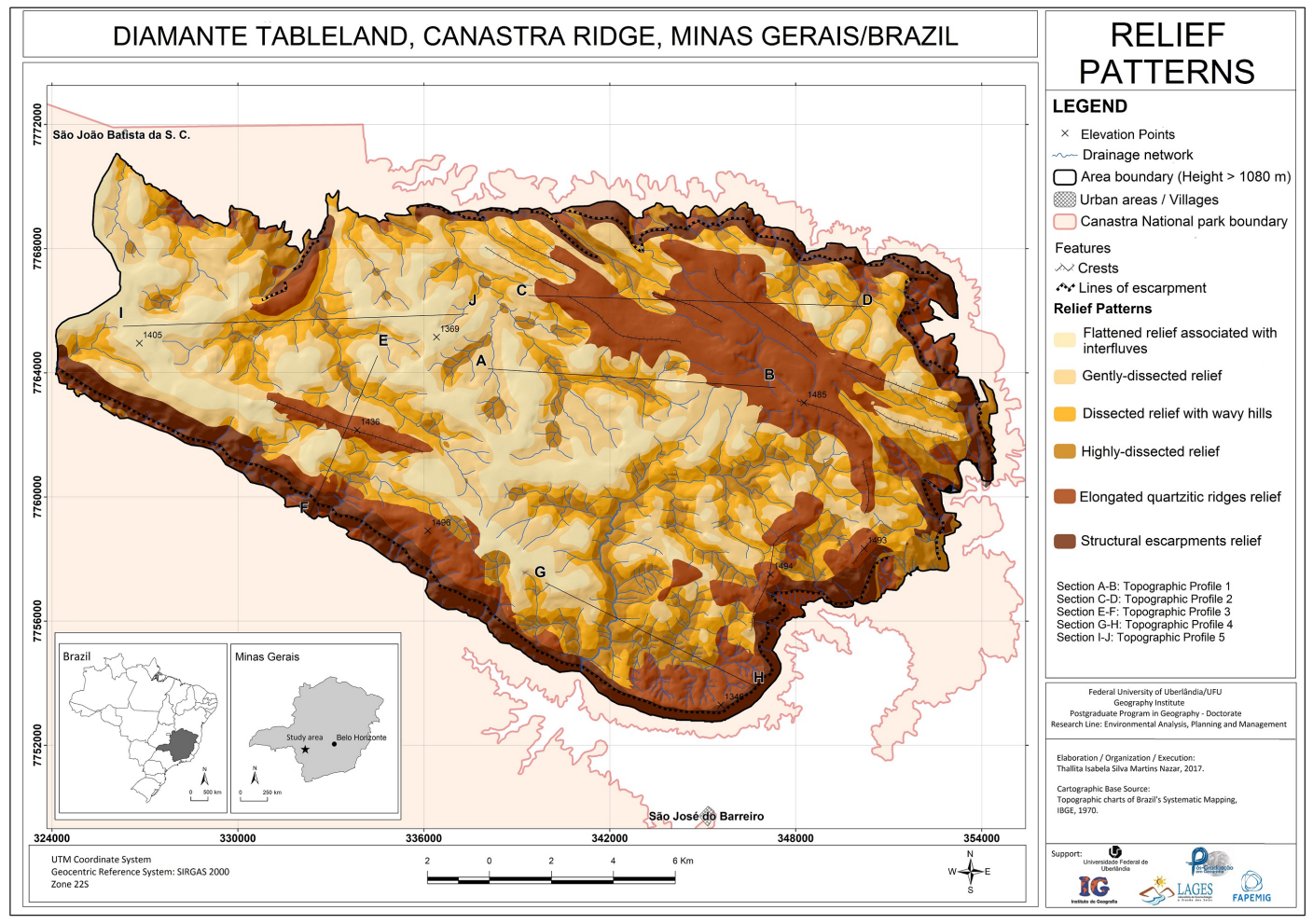

Figure 7 - Relief Units Map of the Diamante Tableland. 
In regard to the unit flattened relief associated with interfluves, $70 \%$ of the total of sandy-clayey-ferruginous geocovers with ferruginous concretions occupy the area, whereas about $40 \%$ of the "murudum" fields or ferruginous bioturbation materials occur in these zones. About $30 \%$ of the total of gravel-sandy materials with ferruginous concretions, which are distributed in flattened tops, cover the unit's area.

For the gently-dissected relief class, the most common geocovers are the undifferentiated "murudum" fields $(>50 \%)$; the gravel-sandy materials with ferruginous concretions $(\sim 45 \%)$; the undifferentiated clayey-sandy materials $(\sim 45 \%)$, the ferruginous "murudum" fields $(40 \%)$, and, lastly, the gravel-sandy materials with organic matter (35\%). In the unit dissected relief with wavy hills, the materials are more evenly distributed, notably the organic geocovers, the undifferentiated sandy-clayey materials, and the undifferentiated gravel-sandy materials, both with $30 \%$ of their areas destined to this kind of relief. In the highly-dissected relief, the organic materials and the undifferentiated gravel-sandy materials provide some $20 \%$ of their areas.

The rocky outcrops and gravel-sandy materials with block chaos geocovers have most of their areas, about $40 \%$ and $30 \%$, respectively, in the elongated quartzitic ridges relief pattern. The undifferentiated colluvial materials, on their turn, mostly occur $(>60 \%)$ in the structural escarpments relief, which also hosts approximately $20 \%$ of the rocky outcrops. The two aforementioned relief classes tend to have a smaller degree of geocover variation out of those existents in the $\mathrm{ChD}$, due to their quartzitic-rock structure, which is quite resistant to weathering processes.

The zonal statistics tables that were rendered to compare the differences between the classes of geocovers were based on the assessment of the LSPs, such as altitude (DTM-HC), declivity, and vertical curvature. The altimetry variation can be verified in Table 1. Such altitudes gently oscillate between classes and the standard deviations are also small in relation to the average, which reiterates the idea of low altimetric variation in the $\mathrm{ChD}$. The escarpments foothills, however, have a large altimetric variation, due to the colluvial materials that happen in them.

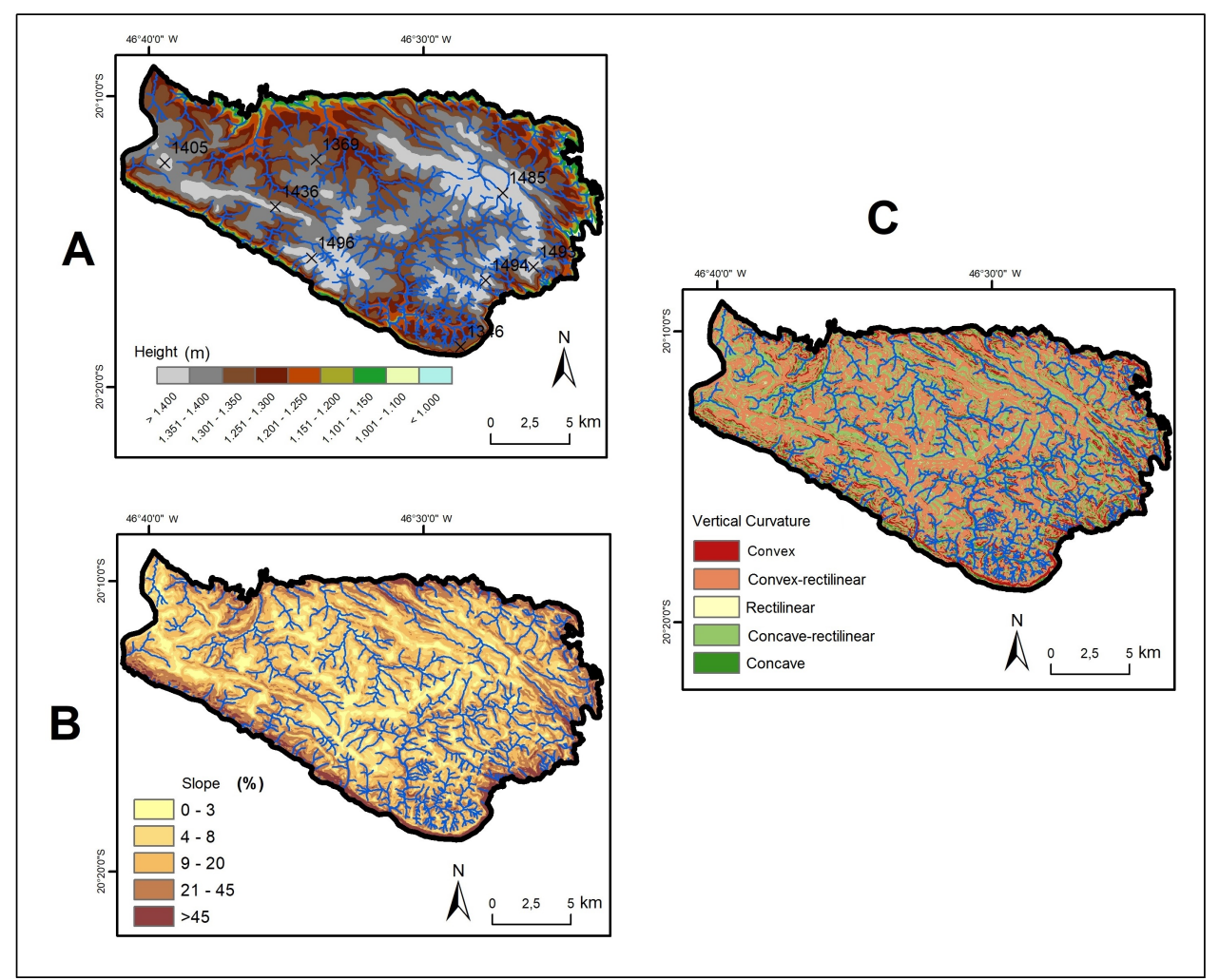

Figure 8 - Used land surface parameters (LSP). A) Altitude; B) Declivity; C) Vertical Curvature. 


\begin{tabular}{|ll|l|l|l|l|l|}
\hline Classes & & MIN & MAX & Range & $\begin{array}{l}\text { Average } \\
\text { (Altitude) }\end{array}$ & $\begin{array}{l}\text { Standard } \\
\text { Deviation }\end{array}$ \\
\hline 1. & Gravel-sandy materials with ferruginous concretions & 1189,83 & 1465,68 & 275,85 & 1371,90 \\
\hline 2. & $\begin{array}{l}\text { Undifferentiated bioturbation materials (“murudum" } \\
\text { fields) }\end{array}$ & 1209,55 & 1425,50 & 215,95 & 1336,64 \\
\hline $\begin{array}{l}\text { Organic matter (peat bogs) associated with valley floors } \\
\text { and humid areas }\end{array}$ & 1024,98 & 1453,80 & 428,82 & 1311,06 \\
\hline 4. & Undifferentiated sandy-clayey materials & 1199,67 & 1443,89 & 244,22 & 1342,95 & 37,02 \\
\hline 5. & Rocky outcrops & 1060,41 & 1495,15 & 434,74 & 1346,83 \\
\hline 6. & Undifferentiated gravel-clayey materials & 1056,53 & 1469,23 & 412,69 & 1310,15 \\
\hline 7. & $\begin{array}{l}\text { Ferruginous bioturbation materials ("murudum" fields) } \\
\text { or with ferruginous concretions }\end{array}$ & 1230,05 & 1460,02 & 229,97 & 1369,28 & 32,75 \\
\hline 8. & Gravel-sandy materials with block chaos & 904,85 & 1493,84 & 589,00 & 1303,06 \\
\hline 9. & Undifferentiated colluvial materials & 1045,49 & 1435,57 & 390,08 & 1136,11 & 89,53 \\
\hline 10. & $\begin{array}{l}\text { Sandy-clayey-ferruginous materials or with ferruginous } \\
\text { concretions }\end{array}$ & 1231,62 & 1429,88 & 198,25 & 1365,19 \\
\hline 11. & Gravel-sandy materials with organic matter & 1251,29 & 1453,74 & 202,45 & 1369,57 \\
\hline
\end{tabular}

Table 1: Zonal Statistics applied to the altitude values in each geocovers class.

With respect to the declivity distribution, the variation between classes is larger, even in their standard deviations (TABLE 2). In spite of that, it is possible to note that the rocky outcrops and gravel-sandy with block chaos geocovers, which are in the more elevated areas and represent pure quartzite, have the higher gradients averages. On the other hand, the ferruginous and lateritic geocovers are associated with the smallest declivity degrees.

\begin{tabular}{|ll|l|l|l|l|l|}
\hline Classes & MIN & MAX & Range & Average & $\begin{array}{l}\text { Standard } \\
\text { Deviation }\end{array}$ \\
\hline 1. & Gravel-sandy materials with ferruginous concretions & 0,03 & 23,75 & 23,72 & 4,08 & 3,02 \\
\hline 2. & $\begin{array}{l}\text { Undifferentiated bioturbation materials (“murudum” } \\
\text { fields) }\end{array}$ & 0,02 & 20,82 & 20,79 & 5,33 & 3,57 \\
\hline 3. & $\begin{array}{l}\text { Organic matter (peat bogs) associated with valley } \\
\text { floors and humid areas }\end{array}$ & 0,01 & 53,16 & 53,15 & 6,77 & 5,17 \\
\hline 4. & Undifferentiated sandy-clayey materials & 0,02 & 24,33 & 24,31 & 6,91 & 3,94 \\
\hline 5. & Rocky outcrops & 0,03 & 58,32 & 58,28 & 12,60 & 8,81 \\
\hline 6. & Undifferentiated gravel-clayey materials & 0,01 & 41,78 & 41,77 & 8,28 & 5,28 \\
\hline 7. & $\begin{array}{l}\text { Ferruginous bioturbation materials ("murudum" } \\
\text { fields) or with ferruginous concretions }\end{array}$ & 0,00 & 24,31 & 24,30 & 4,72 & 3,15 \\
\hline 8. & Gravel-sandy materials with block chaos & 0,00 & 51,79 & 51,79 & 10,42 & 7,39 \\
\hline 9. & Undifferentiated colluvial materials & 0,53 & 56,73 & 56,20 & 22,19 & 8,96 \\
\hline 10. & $\begin{array}{l}\text { Sandy-clayey-ferruginous materials or with } \\
\text { ferruginous concretions }\end{array}$ & 0,02 & 21,44 & 21,42 & 3,37 & 2,54 \\
\hline 11. & Gravel-sandy materials with organic matter & 0,04 & 28,78 & 28,74 & 5,70 & 3,85 \\
\hline
\end{tabular}

Table 2: Zonal statistics applied to the values of declivity in each class of geocovers

Table 3 shows the measures for the vertical curvature indexes. It displays that the averages present significant variation, thus allowing the characterization of each type of geocovers, as well as the association of predominant groups. For instance, the ferruginous materials with concretions, the undifferentiated gravel-sandy materials or with block chaos, and the rocky outcrops prevail either or both of convex and convex-rectilinear slopes. The organic and colluvial materials, in contrast, occur either in or both the concave and concave-rectilinear slopes. 


\begin{tabular}{|c|c|c|c|c|c|}
\hline Classes & MIN & MAX & Range & Average & $\begin{array}{l}\text { Standard } \\
\text { deviation }\end{array}$ \\
\hline (1) Gravel-sandy materials with ferruginous concretions & $-0,87$ & 1,30 & 2,16 & $-0,02$ & 0,09 \\
\hline (2) Undifferentiated bioturbation materials ("murudum" fields) & $-0,87$ & 1,97 & 2,84 & 0,00 & 0,15 \\
\hline $\begin{array}{l}\text { (3) Organic matter (peat bogs) associated with valley floors and } \\
\text { humid areas }\end{array}$ & $-1,49$ & 6,09 & 7,57 & 0,08 & 0,26 \\
\hline (4) Undifferentiated sandy-clayey materials & $-0,89$ & 2,16 & 3,06 & 0,00 & 0,16 \\
\hline (5) Rocky outcrops & $-2,01$ & 5,92 & 7,93 & $-0,04$ & 0,26 \\
\hline (6) Undifferentiated gravel-clayey materials & $-1,31$ & 5,15 & 6,46 & 0,00 & 0,22 \\
\hline $\begin{array}{l}\text { (7) Ferruginous bioturbation materials ("murudum" fields) or with } \\
\text { ferruginous concretions }\end{array}$ & $-0,96$ & 2,16 & 3,12 & $-0,02$ & 0,10 \\
\hline (8) Gravel-sandy materials with block chaos & $-2,97$ & 7,59 & 10,56 & $-0,02$ & 0,25 \\
\hline (9) Undifferentiated colluvial materials & $-2,26$ & 5,85 & 8,11 & 0,04 & 0,35 \\
\hline $\begin{array}{l}\text { (10) Sandy-clayey-ferruginous materials or with ferruginous } \\
\text { concretions }\end{array}$ & $-0,81$ & 1,00 & 1,81 & $-0,02$ & 0,07 \\
\hline (11) Gravel-sandy materials with organic matter & $-0,88$ & 3,69 & 4,57 & 0,00 & 0,17 \\
\hline
\end{tabular}

Table 3: Zonal Statistics applied to the values of vertical curvature in each of the classes of geocovers

It is practically unfeasible to dissociate the analysis of the geocovers from the topographical elements, relief patterns, and litho-structural aspects of the Diamante Tableland. This agrees with the research's initial premise, which was correlated to the conception that such elements are interdependent. The performed analyses and procedures allowed for results that converge with this standpoint. First, we must highlight that the rocky formations of the Diamante Tableland are classified as a set of pure to micaceous quartzites with the interleaving phyllites. The literature approaches such set without any spatial differentiation of each specific type of rock.

Therefore, there was an impossibility to spatially associate each type of surface formation with the existent types of rocks. However, due to the materials distribution, structural aspects, and from the knowledge on the resistance of different types of rocks, it is understood that the rocky substrate conditions distinct patterns of relief forms and, consequently, the types of overlying materials.

That being so, the areas of quartzitic ridges and abundant rocky outcrops express the occurrence of pure quartzite, whereas the dissected reliefs - with hills that vary from smooth, wavy, and highly-waved - include the micaceous quartzites and the phyllites. Thus, the surface of the Diamante Tableland can be considered as endowed with a high morphological and structural complexity, which demands a careful and holistic interpretation of its constituent elements. The findings allowed a broader outlook on the area and displayed a new approach to be applied. The characterization of the surface materials with the relief forms associated with the rocky substrate contributes and may support new research, once this panorama of the $\mathrm{ChD}$ had not yet been explored.

\section{CONCLUSIONS}

The findings allowed the spatial analysis of the distribution of the types of geocovers associated with the land surface parameters and, especially, to the relief units. In regards to the different aspects of the physical environment of the Diamante Tableland, it was possible to determine a deep interrelation between them.

On the one hand, the gravel-sandy geocovers, with or without the occurrence of block chaos usually of incipient thickness - as well as the rocky outcrops, are directly related to the structural axis characterized by elongated ridges that are predominantly sustained by pure quartzites. On the other hand, there are the gravel-sandy-ferruginous geocovers and other rich in iron or concretionary. These represent the smoother reliefs in areas susceptible to more advanced weathering processes, which mainly are in a central structural axis, thus indicating a differentiation of the existent lithological type.Another question of interest is that of the "murudum" fields and active termite hills, which are distributed along the areas whose geocovers present more longer periods of humidity. Their occurrences usually configure the adjacencies of the flattened tops that, as being sustained by ferruginous concretions - which are also 
present along the slopes - that may render a less permeable layer, therefore retaining subsurface water for longer.

In sum, it is understood that the objectives of the research were accomplished, thereby bringing into light important aspects of the Diamante Tableland and opening ways for future research. Thus, it is aspired that this paper inspires future investigations on the different geomorphological, geochemical, and evolutionary aspects of surface materials.

\section{ACKNOWLEDGEMENT}

The authors are grateful for the PhD scholarship of the first author sponsored by the FAPEMIG Foundation for Research Support (PAPG - GEOGRAPHY, 2014-2018), as well as for the project CRA APQ-00231-16 (FAPEMIG), which supports the research.

\section{REFERENCES}

AB' SABER, A.N. Os Domínios de Natureza no Brasil: potencialidades paisagísticas. São Paulo: Ateliê Editorial, 2003.

AMORIM, M.A.F.; AUGUSTIN, C.H.R.R.; MESSIAS, R.M. Dinâmica De Vertente: Evidências A Partir Da Caracterização Das Coberturas Superficiais - Gouveia - Serra Do Espinhaço Meridional - MG. Revista Geonorte, Edição Especial 4, v.10, n.1, p.65-71, 2014.

BIGARELLA, J.J.; MOUSINHO, M.R.; SILVA, J.X. Considerações a respeito da evolução das vertentes. Boletim Paranaense de Geografia, n. 16 e 17, p. 85-116, 1965.

BISHOP, T.F.A. MINASNY, B. Digital soil-terrain modeling: the predictive potential and uncertainty. In: GRUNWALD, S. (Ed). Environmental Soil-Landscape Modeling, CRCPress. Boca Raton, Fla, USA, 2006. p.185-213. https://doi.org/10.1016/S0016-7061(01)00074-X

BRADY, N.C. Natureza e Propriedades dos Solos. $6^{\text {a }}$ ed. Rio de Janeiro, Freitas Bastos, 1983.

CÂMARA, G.; MONTEIRO, A.M.; FUCKS, S.D.; CARVALHO, M.S. Análise Espacial e Geoprocessamento. In: DRUCK, S.; CARVALHO, M.S.; CÂMARA, G.; MONTEIRO, A.V.M. (Eds).

Análise Espacial de Dados Geográficos. Brasília, EMBRAPA, 2004. Capítulo 1.

CAMPY, M.; MACAIRE, J.J. Géologie des formations superficielles: géodynamique - faciès utilisation. Paris; Milan, 1989. 433 p.

CAPUTO, H.P. Mecânica dos solos e suas aplicações. 6. ed. Rio de Janeiro: LTC - Livros Técnicos e Científicos Editora, 1988.

CARVALHO, A.; ROTTA, C.L. Estudos das formações superficiais do município de Atibaia-SP.

Boletim Paulista de Geografia, n. 49, p. 5-22, junho de 1974.

CHAMPAGNAC, L. Dynamique des formations superficielles et analyse morphologique du Val de Ruz. 2005. 149 f. (Mémoire de fi n d'études) - Universite de Neuchatel, Institut de Geographie et de Geologie, Janvier, 2005.

CORRÊA, A.C.B.; FONSÊCA, D.N. Lineamentos de Drenagem e de Relevo como Subsídio para a Caracterização Morfoestrutural e Reativações Neotectônicas da Área da Bacia do Rio Preto, Serra do Espinhaço Meridional - MG. Revista de Geografia, Recife: UFPE - DCG/NAPA, v. especial VIII SINAGEO, n. 1, p. 72-86, Set. 2010.

DANIELS, R.B.; HAMMER, R.D. Soil Geomorphology. New York: John Wiley \& Sons, Inc., 1992.

DEWOLF, Y.; BOURRIÉ, G. (Eds., 2008) Les formations superficielles, genèse, typologie, classification, paysages et environnements, ressources et risques. Resenha de: MORHANGE, C. Les formations superficielles, genèse, typologie, classification, paysages et environnements, ressources et risques. Méditerranée [En ligne], 112, 2009.

DINIZ, A.D.; OLIVEIRA, C.V.; AUGUSTIN, C.H.R.R. Relação Entre Relevo, Classes De Solos e 
Erosão No Espinhaço Meridional. In: V SIMPÓSIO NACIONAL DE GEOMORFOLOGIA E I ENCONTRO SUL-AMERICANO DE GEOMORFOLOGIA, 2004, Santa Maria. Anais... Santa Maria: UFSM - RS, 02 a 07 de Agosto de 2004.

DINIZ, A.D.; OLIVEIRA, C.V.; AUGUSTIN, C.H.R.R. Relações Solos - Superfícies Geomórficas Na Porção Norte Da Bacia Do Ribeirão Chiqueiro - Gouveia, MG. Geonomos， v. 13， n. 1, 2, p. 19-27, 2005.

DOBOS, E. HENGL, T. Soil Mapping Applications. In: HENGL, T.; REUTER, H. I. (Org.).

Geomorphometry: concepts, software, applications. Developments in Soil Science, vol. 33. Amsterdam: Elsevier, 2009. p. 461-479. https://doi.org/10.1016/S0166-2481(08)00020-2

FLORINSKY, I.V. Digital Terrain Analysis in Soil Science and Geology, Academic Press, Boston, 2012.

GUERRA, A.J.T.; CUNHA, S.B. Geomorfologia: uma atualização de bases e conceitos. $12^{\mathrm{a}}$ ed. Rio de Janeiro: Bertrand Brasil, 2013.

GUERRA, S.; PAISANI, J.C. Abrangência Espacial E Temporal Da Morfogênese E Pedogênese No Planalto De Palmas (Pr) E Água Doce (Sc): Subsídio Ao Estudo Da Evolução Da Paisagem Quaternária. Geociências, São Paulo, UNESP, v. 32, n.3, p.501-515, 2013.

HENGL, T.; MACMILLAN, R. A. Geomorphometry - a key to landscape mapping and modelling. In: HENGL, T.; REUTER, H. I. (Org.). Geomorphometry: concepts, software, applications. Developments in Soil Science, vol. 33. Amsterdam: Elsevier, 2009 . p. 433-460. https://doi.org/10.1016/S0166-2481(08)00019-6

HENGL, T.; ROSSITER, D.G. Supervised landform classification to enhance and replace photo-interpretation in semi-detailed soil survey. Soil Science Society of America Journal, v.67, p.1810-1822, 2003.

HERRMANN, L.; SCHULER, U.; RANGUBPIT, W.; ERBE, P.; SURINKUM, A.; ZAREI, M.; STAHR; K. The potential of gamma-ray spectrometry for soil mapping. In: XIX WORLD CONGRESS OF SOIL SCIENCE, SOIL SOLUTIONS FOR A CHANGING WORLD, 2010, Brisbane.

Proocedings... Brisbane, Australia. 1 - 6 August 2010. p. 117-120.

HIRUMA, S. T.; ROCCOMINI, C. Análise morfométrica em neotectònica: o exemplo do Planalto de Campos do Jordão, SP. Revista do Instituto Geológico, IG São Paulo, v. 20, n. 1/2, p. 5-19, jan/dez 2009.

JACOBSON, A.; DHANOTA, J.; GODFREY, J.; JACOBSON, H.; ROSSMAN, Z.; STANISH, A.; WALKER, H.; RIGGIO, J. A novel approach to mapping land conversion using Google Earth with an application to East Africa. Environmental Modelling \& Software, $\quad$ v. $\quad 72, \quad$ p. $\quad 1-9,2015$. https://doi.org/10.1016/j.envsoft.2015.06.011

LEBRET, P.; CAMPY, M.; COUTARD, J.P.; FOURNIGUET, J.; ISAMBERT, M.; LAUTRIDOU, J.P.; LAVILLE, P.; MACAIRE, J.J.; MÉNILLET, F.; MEYER, R. Cartographie des formations superficcielles. Reactualisation des principes de representation à 1/50.000. Geólogie de la France, n. 4, p. 39-54, 1993.

LEPSCH, I.F. Formação e conservação dos solos. $2^{\mathrm{a}}$ ed. São Paulo: Oficina de textos, 2010.

MCBRATNEY, A.B.; MENDONÇA SANTOS, M.L.; MINASNY, B. On digital soil mapping.

Geoderma, Amsterdam, v. 117, n. 1/2, p. 3-52, 2003. https://doi.org/10.1016/S0016-7061(03)00223-4

MMA/IBAMA. Plano de Manejo da Serra da Canastra. 2005. Disponível em: . Acesso em: 20 mai. 2012 .

NAZAR, T.I.S.M.; RODRIGUES, S.C. Relevo do Chapadão do Diamante, Serra da Canastra/MG, Brasil: compartimentação e análise a partir dos aspectos geomorfométricos. Revista Brasileira de Geomorfologia, v. 20, p. 69-88, 2019. http://dx.doi.org/10.20502/rbg.v20i1.1300

NEVES, W.V.; MENEZES; E.P.; OLIVEIRA; F.S.; AUGUSTIN, C.H.R.R.; ARANHA, P.R.A. Estudo 
das coberturas superficiais na interface Cerrado-Vereda no Norte de Minas Gerais. Revista Brasileira de Geomorfologia, São Paulo, v. 16, n. 3, p. 351-367, Jul-Set 2015.

OLIVEIRA, D. B.; MORENO, R. S.; MIRANDA, D. J.; RIBEIRO, C. S.;SEOANE, J. C. S.; MELO, C. L. Elaboração de um mapa de lineamento estrutural e densidade de lineamento através de imagem SRTM , em uma área ao norte do rio Doce, ES. In: XIV SIMPÓSIO BRASILEIRO DE SENSORIAMENTO REMOTO, 2009, Natal. Anais... Natal: INPE, 25-30 abril 2009. p. 4157-4163.

RESENDE, M.; CURI, N.; REZENDE, S.B.; CORRÊA, G.F.; KER, J.C. Pedologia: base para distinção de ambientes. $6^{\text {a }}$ ed. Lavras: Editora UFLA, 2014.

RIBEIRO, V.B.; MANTOVANI, M.S.M.; LOURO, V.H.A. Aerogamaespectrometria e suas aplicações no mapeamento geológico. Terræ Didática, v. 10, p. 29-51, 2013.

RODRIGUES, S. C. Análise Empírico-Experimental da Fragilidade Relevo-Solo no Cristalino do Planalto Paulistano: sub bacia do reservatório Billings. 1998. 265 f. Tese (Doutorado em Geografia Física) - Departamento de Geografia, Universidade de São Paulo, São Paulo, 1998.

ROSS, J.L.S. Ecogeografia do Brasil: subsídios para planejamento ambiental. São Paulo: Oficina de Textos. 2006.

SAADI, A. Ensaio sobre a morfotectônica de Minas Gerais. 1991. 285 f. Tese (Professor Titular) Departamento de Geografia, IGC, Universidade Federal de Minas Gerais, Belo Horizonte, 1991.

SCOTT, K.; PAIN, C. (Eds) Regolith Science.Collingwood Vic., Austrália: Springer, 2009.

SCULL, P.; FRANKLIN, J. CHADWICK, O.A.; MCARTHUR, D. Digital Soil-Terrain Modelling: The Predictive. Progress in Physical Geography, $\quad$ v. 27, $\quad$ n. 2, p. 171-197, 2003. https://doi.org/10.1191/0309133303pp366ra

SIMÕES, L.S.A; MARTINS, J.E.S.; VALERIANO, C.M.; GODOY, A. M.; ARTUR, A. C. Folha Vargem Bonita, SF.23-V-B-I. Projeto Fronteiras de Minas Gerais. Programa Mapeamento Geológico do Estado de Minas Gerais. Contrato CODEMIG 3473, FUNDEP 19967. UFMG: 2015.

SIMÕES, P.M.L.; VALADÃO, R.C.; MESSIAS, R.M.; MACHADO, M.R. Distribuição Espacial De Formações Superficiais Em Um Trecho Da Borda Oeste Do Planalto Do Espinhaço Meridional / MG.

Revista Geonorte, Edição Especial 4, v.10, n.1, p.72-76, 2014.

SIMÕES, P.M.L.; VALADÃO, R.C.; OLIVEIRA, C.V.; OLIVEIRA, F.S.; SANTOS, P. Distribuição Espacial De Formações Superficiais Geneticamente Associadas A Rochas Siliciclásticas - Planalto Do Espinhaço Meridional (MG) - Brasil. Sociedade \& Natureza, Uberlândia, v. 28，n. 1, p. 161-170, $\mathrm{jan} / \mathrm{abr} / 2016$.

SOLLER, D.R., REHEIS, M.C., GARRITY, C.P., VAN SISTINE, D.R. Map database for surficial materials in the conterminous United States: U.S. Geological Survey Data Series 425, 2009.

SOUZA, D. A.; RODRIGUES, S. C. Aspectos Morfoestruturais e Morfoesculturais da Serra da Canastra e Entorno (MG). Revista do Departamento de Geografia-USP, v. 27, p. 47-66, 2014.

SUGUIO, K. Geologia do Quaternário e mudanças ambientais. São Paulo: Oficina de Textos, 2010

TRESCASES, J.J. La Cartographie Géologique Des Formations Superficielles En Nouvelle-Calédonie. In: $9^{\circ}$ CONGRÈS INTERNATIONAL DE L'INQUA,1973, Christchurch. Actes... Christchurch, Nouvelle-Zélande, Décembre 1973. p. 229-230.

TRICART, J. Ecodinâmica. Rio de Janeiro: IBGE, 1977.

WILFORD, J.R. New regolith mapping approaches for old Australian landscapes. 2014. 183 f. Ph. D. thesis (Geosciences) - The University of Adelaide, South Australia., 2014.

WILFORD, J., MINTY, B. The use of airborne gamma-ray imagery for mapping soils and understanding landscape processes. In: LAGACHERIE, P., MCBRATNEY, A.B., VOLTZ, M. (Eds.), Digital Soil Mapping an Introductory Perspective. Developments in Soil Science,v. 31, Elsevier, p. 207-218, 2006. http://dx.doi.org/10.1016/ S0166-2481(06)31016-1. 